\title{
Badania wpływu zwiększonej zawartości bioetanolu w benzynie silnikowej na wartość liczby oktanowej
}

\begin{abstract}
W artykule przedstawiono wyniki badań wpływu różnych zawartości bioetanolu na eksploatacyjne parametry typowej benzyny bazowej węglowodorowej. Opierając się na najnowszych normach PN-EN ISO oznaczania odporności benzyny silnikowej na spalanie stukowe metodą badawczą (LOB) i metodą motorową (LOM), przeprowadzono na stanowiskach silnikowych CFR Dresser Waukesha (USA) wielokrotne badania liczb oktanowych paliw zawierających bioetanol w przedziale 15-25\% $(V / V)$ i porównawczo $10 \%(V / V)$.
\end{abstract}

Słowa kluczowe: biopaliwa, bioetanol, liczba oktanowa.

\section{Research on the influence of increased bioethanol content in gasoline engine on the value of octane numbers}

\begin{abstract}
The article presents results of research on the impact of various bioethanol content, on the operational parameters of a typical hydrocarbon base gasoline. Based on the latest standard PN-EN ISO, determination of the resistance of gasoline engine knock by (RON) research method and the (MON) motor method, multiple research octane numbers of fuels containing bio-ethanol in the range 15 to $25 \%(V / V)$ and comparatively $10 \%(V / V)$ were conducted on CFR Dresser Waukesha US motor positions.
\end{abstract}

Key words: biofuels, bioethanol, octane number.

\section{Wprowadzenie}

Analizując światowy rozwój komponowania benzyn silnikowych o zwiększonej zawartości bioetanolu oraz obserwując podejmowane przez polityków działania ekologiczne we wszystkich państwach członkowskich Unii Europejskiej w kierunku zwiększania zawartości bioetanolu w benzynie silnikowej, można stwierdzić, że w paliwach do silników ZI systematycznie zacznie ubywać benzyny.

W związku z tym w poszczególnych krajach tworzone są specyfikacje jakościowe paliw etanolowych, aby umożliwić danemu krajowi wywiązanie się z przyjętych zobowiązań w zakresie energii odnawialnej. Powszechne stosowanie paliw etanolowych w silnikach o zapłonie iskrowym wymaga przeprowadzenia badań w szerokim zakresie, nie tylko w celu oceny tych paliw pod względem spełnienia właściwości normowanych, ale także dla oceny wpływu etanolu na właściwości użytkowe paliw, ujęte m.in. w Światowej Karcie Paliw [6].
Bioetanol to odwodniony alkohol etylowy otrzymywany z produktów roślinnych (zboża, ziemniak, burak cukrowy itp.), a w klimacie ciepłym produkowany głównie z trzciny cukrowej. Bioetanol może być stosowany jako paliwo samochodowe samo w sobie w specjalnie przystosowanych silnikach lub po zmieszaniu z benzyną. Dodatkowy tlen występujący w alkoholu zwiększa liczbę oktanową paliwa oraz zmniejsza o $20 \div 30 \%$ stężenie tlenku węgla i do $10 \%$ stężenie węglowodorów w gazach spalinowych, w stosunku do składu spalin benzyn niezawierających etanolu. Alkohol etylowy może być również przetwarzany na ETBE (eter etylo-tert-butylowy), który stanowi dodatek do benzyny [8].

W Brazylii do zasilania silników o zapłonie iskrowym (ZI) z powodzeniem od wielu lat stosuje się czysty bioetanol i benzynę silnikową zawierającą do 25\% bioetanolu, a w USA od stycznia 2011 roku amerykańska Agencja Ochrony Środowiska (EPA) zwiększyła zakres udziału 
bioetanolu w benzynie silnikowej sprzedawanej na stacjach paliw do $15 \%$ [9].

Prawo europejskie dopuszcza sprzedaż paliwa E10 (benzyny silnikowej z 10-proc. udziałem bioetanolu), co jest też zgodne z przepisami dyrektywy 2009/30/WE z dnia 23 kwietnia 2009 r. w zakresie wprowadzenia wymagań jakościowych dla benzyn silnikowych z maksymalną zawartością tlenu do $3,7 \%(\mathrm{~m} / \mathrm{m})$ oraz od $5 \%$ do $10 \%(\mathrm{~V} / \mathrm{V})$ bioetanolu.

Jednak ze sprawozdania Komisji Europejskiej dla Parlamentu Europejskiego i Rady Jakość benzyny i oleju napędowego stosowanych $w$ transporcie drogowym w Unii Europejskiej (UE): jedenaste sprawozdanie roczne (rok sprawozdawczy 2012) z dnia 10 marca 2014 r. wynika, że udział na rynku europejskim benzyny E10 jest wciąż nieduży i sprzedawana jest ona obecnie jedynie w trzech krajach (Niemcy, Francja i Finlandia). Podkreślono jednocześnie, że brak podjęcia działań przez państwa UE, które nie wdrożyły w pełni przepisów dyrektywy 2009/30/WE do krajowego porządku prawnego, stanowić będzie podstawę dla Komisji Europejskiej do wniesienia skargi do Trybunału Sprawiedliwości UE z wnioskiem o nałożenie kary finansowej.

Efektem tego było przygotowanie przez stronę polską rozporządzenia Ministra Gospodarki z dnia 3 listopada 2014 r. zmieniającego rozporządzenie w sprawie wymagań jakościowych dla paliw ciekłych, częściowo wdrażającego dyrektywę 2009/30/WE do polskiego porządku prawnego. Określono w nim między innymi wymagania jakościowe dla benzyn silnikowych E10 oraz ustalono okres przejściowy do 31 grudnia 2020 r., w trakcie którego dostawcy paliw są zobowiązani do zagwarantowania dostępności na rynku również benzyn silnikowych E5, zawierających do 5\% ( V/V) bioetanolu i $2,7 \%(\mathrm{~m} / \mathrm{m})$ tlenu [1].

Według założeń rozporządzenia dopuszczenie do obrotu benzyn silnikowych z zawartością do $10 \%(\mathrm{~V} / \mathrm{V})$ biokomponentów ma przyczynić się do ułatwienia realizacji obowiązku spełnienia Narodowego Celu Wskaźnikowego (NCW), który nakazuje producentom paliw systematyczne zwiększanie udziału biokomponentów i biopaliw ciekłych na krajowym rynku paliwowym.

W Unii Europejskiej trwają już jednak konsultacje dotyczące możliwości dalszego systematycznego zwiększania udziału bioetanolu w benzynie silnikowej, co znalazło odzwierciedlenie w programie Horyzont 2020, zaproponowanym przez Europejski Komitet Normalizacyjny (Comité Eu- ropéen de Normalisation - CEN) i Europejski Komitet Normalizacyjny Elektrotechniki (Comité Européen de Normalisation Electrotechnique - CENELEC).

Podstawowym zadaniem CEN-CENELEC jest opracowywanie, przyjmowanie i rozpowszechnianie norm europejskich oraz innych dokumentów normalizacyjnych we wszystkich obszarach gospodarki.

Członkami i partnerami Europejskiego Komitetu Normalizacyjnego i Europejskiego Komitetu Normalizacyjnego Elektrotechniki są krajowe jednostki (organy, instytucje) normalizacyjne, w tym od 1 stycznia 2004 roku Polski Komitet Normalizacyjny (PKN). CEN-CENELEC ma obowiązek wprowadzania norm EN do systemów norm krajowych i wycofywania dotychczasowych norm sprzecznych z wprowadzanymi, tworząc tym samym jednolity i spójny europejski system normalizacyjny [4].

4 czerwca 2014 roku Europejski Komitet Normalizacyjny przedstawił projekt Horyzont 2020, obejmujący program badań silnikowych dla nowych rodzajów biopaliw oraz rozwój norm dla biopaliw w ramach umowy partnerskiej CEN-CENELEC. Projekt ten został poddany konsultacji przez Komisję Europejską (European Commission - EC), grupę czołowych firm naftowych prowadzących badania w zakresie ochrony środowiska CONCAWE (Conservation of Clean Air and Water in Europe) oraz Stowarzyszenie Europejskich Producentów Samochodów (Association des Constructeurs Européens d'Automobiles - ACEA). Wskazano, że głównym tematem możliwym do realizacji w tego typu projekcie powinny być badania wpływu zawartości bioetanolu w benzynie silnikowej E20/25 (benzyna silnikowa zawierająca od $20 \%$ do $25 \%$ ( V/V) bioetanolu) na liczby oktanowe i zmiany lotności benzyny w zależności od procentowego udziału związku tlenowego, z zaznaczeniem, że prowadzone prace powinny mieć charakter badawczy albo związany z poprawą odpowiednich istniejących już norm [10].

Ponadto Europejski Komitet Normalizacyjny i Elektrotechniki CEN-CENELEC, bazując na własnych doświadczalnych badaniach prowadzonych w ramach warsztatów „Business Plan for the CEN Workshop” dla paliwa E20, zaproponował przykładowy zakres badań parametrów fizykochemicznych według EN 228 dla potencjalnej przyszłej specyfikacji benzyny silnikowej E20/25, zawierającej od 20\% do 25\% ( V/V) bioetanolu (tablica 3) [13].

\section{Część badawcza}

Przed przystąpieniem do badań ustalono, że planowany zakres oznaczeń liczb oktanowych badawczej i motorowej jest zgodny z najnowszymi wydaniami norm
PN-EN ISO 5164:2014-08 (metoda badawcza - LOB) i PN-EN ISO 5163:2014-08 (metoda motorowa - LOM). Powyższe normy zastępują stare wydania z 2007 roku. 
Norma PN-EN ISO 5164:2014-08 może być stosowana w całym zakresie oznaczania liczb oktanowych od 0 LOB do 120 LOB, ale zakłada się, że jej typowy zakres roboczy dla znajdujących się w obrocie handlowym paliw przeznaczonych do zasilania samochodowych silników o zapłonie iskrowym powinien mieścić się w zakresie od 88 LOB do 101 LOB [12].

Natomiast norma PN-EN ISO 5163:2014-08 też może być stosowana w całym swoim zakresie oznaczania liczb oktanowych od 0 LOM do 120 LOM, ale w tym przypadku zakłada się, że jej typowy zakres oznaczeń dla znajdujących się $\mathrm{w}$ obrocie handlowym paliw przeznaczonych do zasilania samochodowych silników o zapłonie iskrowym powinien mieścić się w granicach od 80 LOM do 90 LOM, a dla paliw lotniczych obejmować liczby od 98 LOM do 102 LOM [11].

Najnowsze wydania norm na LOB i LOM mogą być stosowane do paliw zawierających związki tlenowe o zawartości tlenu nie większej niż 4\% $(\mathrm{m} / \mathrm{m})$ i do benzyn zawierających do $25 \%(V / V)$ etanolu $[11,12]$. Poprzednie wydania norm z $2007 \mathrm{r}$. określały tylko zawartość tlenu do 4\% $(\mathrm{m} / \mathrm{m})$ bez dopuszczalnej procentowej zawartości etanolu w benzynie silnikowej.

Ponadto w normach PN-EN ISO z 2014 r. dotyczących oznaczania odporności benzyny samochodowej na spalanie stukowe metodą badawczą i motorową oszacowano powtarzalność i odtwarzalność wyników oznaczanych liczb oktanowych paliw zawierających od $15 \%$ do $25 \%(V / V)$ etanolu (tablica 1).

Dla porównania w tablicy 2 przedstawiono precyzję metod badawczych LOB i LOM dla pozostałych paliw zawierających związki tlenowe, o zawartości tlenu nie większej niż 4\% $(\mathrm{m} / \mathrm{m})$, badanych przy ciśnieniu atmosferycznym $94,6 \mathrm{kPa}$ i wyższym.

W ramach realizacji pracy badawczej, polegającej na ustaleniu wpływu zwiększonego udziału biokomponentów w benzynie silnikowej na wartość liczby oktanowej, przygotowano trzy partie paliw silnikowych o podwyższonej zawartości bioetanolu Alpinus w krajowej bazowej benzynie silnikowej o klasie lotności odpowiadającej okresowi przejściowemu lub zimowemu i porównawczo partię bazowej benzyny silnikowej zawierającej $10 \%(V / V)$ bioetanolu.

Poniżej podano opis i skład próbek bazowej benzyny silnikowej i etanolu przygotowanych do badań silnikowych liczb oktanowych w dziesięciu powtórzeniach dla każdej partii:

- E10 - bazowa benzyna silnikowa zawierająca $10 \%(V / V)$ bioetanolu,
- E15 - bazowa benzyna silnikowa zawierająca 15\% $(V / V)$ bioetanolu,

- E20 - bazowa benzyna silnikowa zawierająca 20\% $(V / V)$ bioetanolu,

- E25 - bazowa benzyna silnikowa zawierająca 25\% $(V / V)$ bioetanolu.

Analizę właściwości fizykochemicznych próbek paliw etanolowych E15-E25 i porównawczo E10, wykonaną w INiG - PIB zgodnie z „Business Plan for the CEN Workshop" [11] i normą PN-EN 228:2013-04, przedstawiono w tablicy 3 .

Na podstawie zamieszczonej w tablicy 3 analizy właściwości fizykochemicznych oraz bazując na własnych wstępnych badaniach liczb oktanowych dla zestawionych paliw E10-E25, ustalono przewidywany zakres oznaczalności LOB od 95 do 100 i LOM od 85 do 90, który wyklucza stosowanie mieszanin podstawowych paliw wzorcowych (PRF) i rozcieńczonego tetraetylku ołowiu (TEL).

Podstawowe paliwa wzorcowe (primary reference fuels - PRF), jakimi są izooktan o $\mathrm{LO}=100$ i n-heptan o $\mathrm{LO}=0$, oraz rozcieńczony tetraetylek ołowiu (tetraethyl lead - TEL) nazywane są paliwami „nawiasującymi” i stanowią niezbędny materiał do prowadzenia oznaczeń liczb oktanowych benzyn silnikowych na stanowiskowych jednostkach badawczych CFR [11, 12].

Paliwa nawiasujące dobrano, zestawiając je w ten sposób, żeby największa dopuszczalna różnica pomiędzy ich wartościami była zgodna $\mathrm{z}$ wytycznymi zamieszczonymi w tablicy 4.

Tablica 1. Powtarzalność i odtwarzalność wyników oznaczeń liczb oktanowych paliw zawierających od $15 \%$ do $25 \%(V / V)$ etanolu $[11,12]$

\begin{tabular}{|c|c|c|c|}
\hline $\begin{array}{c}\text { Liczba } \\
\text { oktanowa }\end{array}$ & $\begin{array}{c}\text { Powtarzalność } \\
(r)\end{array}$ & $\begin{array}{c}\text { Odtwarzalność } \\
(R)\end{array}$ & $\begin{array}{c}\text { Norma } \\
\text { PN-EN ISO }\end{array}$ \\
\hline LOB & $r=0,3$ & $R=0,8$ & $5164: 2014-08$ \\
\hline LOM & $r=0,4$ & $R=1,1$ & $5163: 2014-08$ \\
\hline
\end{tabular}

Tablica 2. Powtarzalność i odtwarzalność wyników oznaczeń liczb oktanowych paliw zawierających związki tlenowe, o zawartości tlenu nie większej niż 4\% $(\mathrm{m} / \mathrm{m})$, badanych przy ciśnieniu atmosferycznym 94,6 kPa i wyższym [11, 12]

\begin{tabular}{|c|c|c|c|c|}
\hline $\begin{array}{c}\text { Liczba } \\
\text { oktanowa }\end{array}$ & $\begin{array}{c}\text { Średnia wartość } \\
\text { liczby oktanowej }\end{array}$ & Powtarzalność $(r)$ & Odtwarzalność $(R)$ & $\begin{array}{c}\text { Norma } \\
\text { PN-EN ISO }\end{array}$ \\
\hline \multirow{3}{*}{ LOB } & poniżej 90,0 & aktualnie brak danych & aktualnie brak danych & \multirow{2}{*}{ 5164:2014-08 } \\
\cline { 2 - 4 } & 90,0 do 100,0 & $r=0,2$ & $R=0,7$ & \\
\cline { 2 - 4 } & 101,0 & aktualnie brak danych & $R=1,0$ & \multirow{2}{*}{ 5163:2014-08 } \\
\hline \multirow{3}{*}{ LOM } & poniżej 80,0 & aktualnie brak danych & aktualnie brak danych & \\
\cline { 2 - 4 } & 80,0 do 90,0 & $r=0,2$ & $R=0,9$ & \\
\cline { 2 - 4 } & 90,0 do 102,0 & aktualnie brak danych & aktualnie brak danych & \\
\hline
\end{tabular}


Tablica 3. Analiza fizykochemiczna przeprowadzona w INIG - PIB dla próbek paliw etanolowych E15-E25 i porównawczo E10 na podstawie wymagań CEN-CENELEC, warsztatów „Business Plan for the CEN Workshop” [13] i normy PN-EN 228:2013-04

\begin{tabular}{|c|c|c|c|c|c|c|c|c|}
\hline & Parametr & $\begin{array}{l}\text { Wyniki } \\
\text { badań } \\
\text { INiG - PIB } \\
\text { dla paliwa } \\
\underline{\text { E15 }}\end{array}$ & $\begin{array}{c}\text { Wyniki } \\
\text { badań } \\
\text { INiG - PIB } \\
\text { dla paliwa } \\
\underline{\text { E20 }}\end{array}$ & $\begin{array}{l}\text { Wyniki } \\
\text { badań } \\
\text { INiG - PIB } \\
\text { dla paliwa } \\
\underline{\text { E25 }}\end{array}$ & $\begin{array}{l}\text { Wymagania } \\
\text { według } \\
\text { CEN }\end{array}$ & $\begin{array}{l}\text { Wyniki } \\
\text { badań } \\
\text { INiG - PIB } \\
\text { dla paliwa } \\
\underline{\text { E10 }}\end{array}$ & $\begin{array}{l}\text { Wymagania } \\
\text { według } \\
\text { PN-EN } \\
\text { 228:2013-04 }\end{array}$ & $\begin{array}{l}\text { Metody } \\
\text { badań paliw } \\
\text { E10-E25 }\end{array}$ \\
\hline 1. & Gęstość w $15^{\circ} \mathrm{C}\left[\mathrm{kg} / \mathrm{m}^{3}\right]$ & 743 & 745 & 749 & $720 \div 775$ & 742 & $720 \div 775$ & $\begin{array}{c}\text { PN-EN ISO } \\
12185\end{array}$ \\
\hline 2. & Prężność par (DVPE) [kPa] & 81,6 & 82,6 & 81,0 & $\begin{array}{c}60,0(\mathrm{~A})- \\
100,0(\mathrm{~F} / \mathrm{F} 1)\end{array}$ & 83,0 & $\begin{array}{l}45,0 \div 60,0^{*} \\
45,0 \div 90,0^{* *} \\
60,0 \div 90,0^{* * *}\end{array}$ & $\begin{array}{l}\text { PN-EN } \\
13016-1\end{array}$ \\
\hline 3. & \multicolumn{7}{|l|}{ Destylacja: } & \multirow{6}{*}{$\begin{array}{l}\text { PN-EN ISO } \\
3405\end{array}$} \\
\hline a) & $\begin{array}{c}- \text { do } 70^{\circ} \mathrm{C} \text { odparowuje } \\
\quad[\%(V / V)]\end{array}$ & 53,4 & 50,6 & 47,0 & \multirow{5}{*}{$\begin{array}{l}\text { w trakcie } \\
\text { specyfikacji }\end{array}$} & 51,1 & $\begin{array}{l}22,0 \div 50,0^{*} \\
24,0 \div 52,0^{* *} \\
24,0 \div 52,0^{* * *}\end{array}$ & \\
\hline b) & $\begin{array}{l}\text { - do } 100^{\circ} \mathrm{C} \text { odparowuje } \\
{[\%(V / V)]}\end{array}$ & 68,3 & 73,2 & 77,9 & & 63,6 & $46,0 \div 72,0$ & \\
\hline c) & $\begin{array}{l}\text { - do } 150^{\circ} \mathrm{C} \text { odparowuje } \\
{[\%(V / V)]}\end{array}$ & 91,3 & 91,9 & 92,3 & & 91,1 & $\min .75,0$ & \\
\hline d) & - koniec destylacji FBP $\left[{ }^{\circ} \mathrm{C}\right]$ & 185,1 & 183,5 & 181,7 & & 185,9 & maks. 210 & \\
\hline e) & - pozostałość [\% $(V / V)]$ & 1,6 & 1,5 & 1,4 & & 1,7 & maks. 2 & \\
\hline \multirow{3}{*}{4.} & \multicolumn{7}{|l|}{ Zawartość węglowodorów: } & \multirow{3}{*}{ PN-EN 15553} \\
\hline & - olefinowych [\% $(V / V)]$ & 8,4 & 7,4 & 8,1 & maks. 15,0 & 9,0 & maks. 18,0 & \\
\hline & - aromatycznych $[\%(V / V)]$ & 25,3 & 26,2 & 22,8 & maks. 30,0 & 32,6 & maks. 35,0 & \\
\hline 5. & Zawartość benzenu $[\%(V / V)]$ & 0,76 & 0,72 & 0,67 & maks. 1,00 & 0,80 & maks. 1,00 & PN-EN 238 \\
\hline 6. & Zawartość tlenu $[\%(\mathrm{~m} / \mathrm{m})]$ & 5,61 & 7,22 & 9,21 & $5,5 \div 8,2$ & 3,68 & maks. 3,7 & \multirow{9}{*}{$\begin{array}{l}\text { PN-EN } \\
1601-1\end{array}$} \\
\hline 7. & Związki tlenowe: & & & & & & & \\
\hline a) & - metanol $[\%(V / V)]$ & $<0,17$ & $<0,17$ & $<0,17$ & maks. 3,0 & $<0,17$ & maks. 3,0 & \\
\hline b) & - etanol $[\%(V / V)]$ & 15,1 & 19,5 & 25,0 & $15 \div 20$ & 9,9 & maks. 10,0 & \\
\hline c) & $\begin{array}{l}\text { - alkohol izopropylowy } \\
{[\%(V / V)]}\end{array}$ & $<0,17$ & $<0,17$ & $<0,17$ & maks. 12,0 & $<0,17$ & maks. 12,0 & \\
\hline d) & $\begin{array}{l}\text { - alkohol tert-butylowy } \\
{[\%(V / V)]}\end{array}$ & $<0,17$ & $<0,17$ & $<0,17$ & maks. 15,0 & $<0,17$ & maks. 15,0 & \\
\hline e) & $\begin{array}{l}- \text { alkohol izobutylowy } \\
{[\%(V / V)]}\end{array}$ & $<0,17$ & $<0,17$ & $<0,17$ & maks. 15,0 & $<0,17$ & maks. 15,0 & \\
\hline f) & $\begin{array}{c}\text { - etery zawierające } 5 \text { lub } \\
\text { więcej atomów węgla } \\
\text { w cząsteczce }[\%(V / V)]\end{array}$ & $<0,17$ & $<0,17$ & $<0,17$ & maks. 22,0 & $<0,17$ & maks. 22,0 & \\
\hline g) & $\begin{array}{l}\text { - inne związki organiczne } \\
\text { zawierające tlen }[\%(V / V)]\end{array}$ & $<0,17$ & $<0,17$ & $<0,17$ & maks. 15,0 & $<0,17$ & maks. 15,0 & \\
\hline 8. & Zawartość siarki $[\mathrm{mg} / \mathrm{kg}]$ & 4,6 & 3,9 & 3,3 & maks. 10,0 & 6,0 & maks. 10,0 & $\begin{array}{l}\text { PN-EN ISO } \\
20884\end{array}$ \\
\hline 9. & Zawartość ołowiu [mg/l] & $<2,5$ & $<2,5$ & $<2,5$ & maks. 5,0 & $<2,5$ & maks. 5,0 & PN-EN 237 \\
\hline 10. & Zawartość manganu [mg/l] & - & - & - & maks. 2,0 & - & maks. 2,0 & PN-EN 16135 \\
\hline
\end{tabular}

* Okres letni - od 1 maja do 30 września.

** Okres przejściowy - od 1 marca do 30 kwietnia oraz od 1 października do 31 października.

*** Okres zimowy - od 1 listopada do końca lutego.

A-F/F1: klasy lotności dla parametru prężność par, zależne od krajowych warunków klimatycznych panujących w danym państwie. 
Tablica 4. Największe dopuszczalne różnice liczb oktanowych (badawczej, motorowej) nawiasujących mieszanin podstawowych paliw wzorcowych PRF i TEL $[11,12]$

\begin{tabular}{|c|c|}
\hline $\begin{array}{c}\text { Zakres LOB/LOM } \\
\text { próbki paliwa }\end{array}$ & $\begin{array}{c}\text { Największa dopuszczalna różnica LO pomiędzy mieszaninami } \\
\text { podstawowych paliw wzorcowych PRF i TEL }\end{array}$ \\
\hline 40 do 72 & dopuszczalna różnica LOB/LOM dla mieszanin PRF do 4,0 \\
\hline 72 do 80 & dopuszczalna różnica LOB/LOM dla mieszanin PRF do 2,4 \\
\hline 80 do 100 & dopuszczalna różnica LOB/LOM dla mieszanin PRF do 2,0 \\
\hline 100,0 do 100,7 & stosować tylko mieszaniny PRF o LOB/LOM 100,0 i 100,7 \\
\hline 100,7 do 101,3 & stosować tylko mieszaniny PRF o LOB/LOM 100,7 i 101,3 \\
\hline 101,3 do 102,5 & stosować tylko mieszaniny PRF o LOB/LOM 101,3 i 102,5 \\
\hline 102,5 do 103,5 & stosować tylko mieszaniny PRF o LOB/LOM $102,5 \mathrm{i} 103,5$ \\
\hline 103,5 do 108,6 & stosować mieszaniny PRF z TEL zawierające $0,053 \mathrm{ml} /$ litr $(0,2 \mathrm{ml} / \mathrm{US}$ gal.) \\
\hline 108,6 do 115,5 & stosować mieszaniny PRF z TEL zawierające $0,132 \mathrm{ml} / \mathrm{litr}(0,5 \mathrm{ml} / \mathrm{US}$ gal.) \\
\hline 115,5 do 120,3 & stosować mieszaniny PRF z TEL zawierające $0,264 \mathrm{ml} / \mathrm{litr}(1,0 \mathrm{ml} / \mathrm{US}$ gal.) \\
\hline
\end{tabular}

Opisane powyżej właściwe przygotowanie warsztatu badawczego oraz określenie zakresu oznaczalności LO i zestawienie odpowiednich znormalizowanych paliw wzorcowych umożliwiły przystąpienie do prowadzenia wielokrotnych oznaczeń liczb oktanowych dla przygotowanych paliw E15-E25 i porównawczo E10, zgodnie z metodyką badań zawarta w normach PN-EN ISO 5164:2014-08 (LOB) i PN-EN ISO 5163:2014-08 (LOM).

Badanie wpływu zwiększonego udziału bioetanolu w benzynie silnikowej na wartość liczby oktanowej postanowiono ocenić w warunkach powtarzalności, czyli warunkach, w których niezależne wyniki takich samych jednostek badania są otrzymywane dla tej samej próbki paliwa, za pomocą tej samej metody, w tym samym laboratorium, przez tego samego operatora, z użyciem tego samego wyposażenia, w krótkich odstępach czasu [2].

Przed rozpoczęciem badań liczb oktanowych dla każdej przygotowanej serii próbek paliw etanolowych sprawdzano, czy silniki badawcze LOB i LOM spełniają wszystkie wymagania dotyczące regulacji i warunków użytkowania oraz czy znajdują się one w stanie ustabilizowanym i zgodnym $\mathrm{z}$ wymaganiami odpowiednich norm PN-EN ISO i instrukcji technicznych silników CFR.

Priorytetem było wzorcowanie jednostek badawczych dla każdego poziomu oznaczalności LO, zależnego od przybliżonej liczby oktanowej oznaczanej dla danej serii próbek paliw E10-E25, w którym kwalifikowano silniki LOB i LOM jako nadające się do wykonywania oznaczeń, poprzez ocenę odpowiedniej znormalizowanej mieszaniny paliwa toluenowego. Mieszaninę tę zestawia się w proporcjach objętościowych następujących składników: wzorcowego toluenu, izooktanu i n-heptanu, które mają wywzorcowane liczby oktanowe i oznaczone granice tolerancji wartości wzorcowania Skład mieszaniny i związaną z nią wielkość liczby oktanowej dobiera się każdorazowo do zakresu LOB i LOM, w którym oznaczane są próbki paliw silnikowych. Wykonane wcześniej badania wstępne liczb oktanowych dla przygotowanych próbek paliw E10-E25 pozwoliły wyznaczyć odpowiednie przedziały liczb oktanowych, w zależności od których wzorcowano silniki badawcze CFR i prowadzono standardowe badania LOB, LOM [3].

Po każdej serii wielokrotnych oznaczeń liczb oktanowych dla danej partii paliw E10-E25 - przeprowadzano czynności obsługowe układów dolotowych silników badawczych CFR, kontrolując wszystkie zespoły i podzespoły zasilające silniki w badane paliwo i mieszankę paliwowo-powietrzną.

Zabiegi te były związane z oceną i wyeliminowaniem nalotów, osadów i laków powstających po badaniach LO dla każdej partii paliwa bioetanolowego, które mogłyby prowadzić do nieprawidłowej pracy jednostek badawczych CFR i przekładać się w sposób znaczący na jakość i wartość oznaczanych liczb oktanowych.

\section{Wyniki}

Uzyskane w Laboratorium Badań Silnikowych i Trybologicznych INiG - PIB wyniki badań liczb oktanowych benzyn silnikowych zawierających bioetanol w zakresie
$15 \div 25 \%(V / V)$ i porównawczo $10 \%(V / V)$ zamieszczono w tablicach 5-8 oraz przedstawiono graficznie na rysunkach 1-4. 


\section{NAFTA-GAZ}

Tabela 5. Wyniki oznaczeń LOB według PN-EN ISO 5164:2014-08 i LOM według PN-EN ISO 5163:2014-08 paliwa E10

\begin{tabular}{|c|c|c|c|c|}
\hline $\begin{array}{c}\text { Średnia wartość LO } \\
\text { paliwa E10 }\end{array}$ & Powtarzalność & $\begin{array}{c}\text { Górna granica } \\
\text { powtarzalności }\end{array}$ & $\begin{array}{c}\text { Dolna granica } \\
\text { powtarzalności }\end{array}$ & $\begin{array}{c}\text { Liczba powtórzeń } \\
\text { badań LO }\end{array}$ \\
\cline { 1 - 3 } $\mathrm{LOB}=96,31$ & 0,2 & $\mathrm{LOB}_{\mathrm{G}}=96,51$ & $\mathrm{LOB}_{\mathrm{D}}=96,11$ & \multirow{2}{*}{10} \\
\cline { 1 - 3 } & 0,2 & $\mathrm{LOM}_{\mathrm{G}}=86,69$ & $\mathrm{LOM}_{\mathrm{D}}=86,29$ & \\
\hline
\end{tabular}

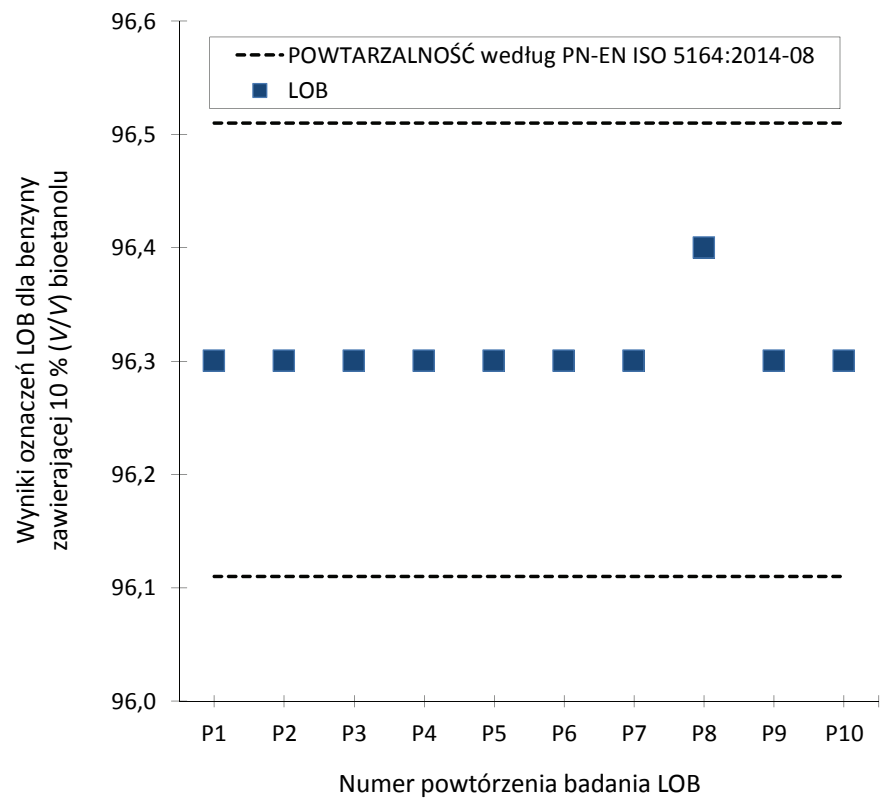

Rys. 1a. Wyniki oznaczeń liczby oktanowej badawczej (LOB) dla paliwa E10

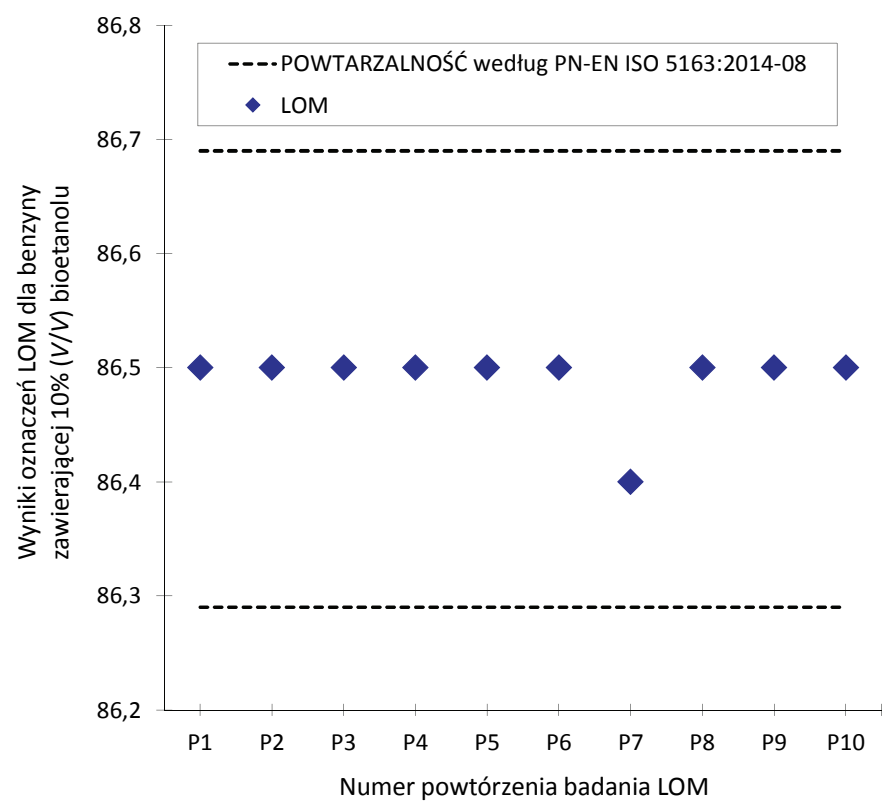

Rys. 1b. Wyniki oznaczeń liczby oktanowej motorowej (LOM) dla paliwa E10

Tablica 6. Wyniki oznaczeń LOB według PN-EN ISO 5164:2014-08 i LOM według PN-EN ISO 5163:2014-08 paliwa E15

\begin{tabular}{|c|c|c|c|c|}
\hline $\begin{array}{c}\text { Średnia wartość LO } \\
\text { paliwa E15 }\end{array}$ & Powtarzalność & $\begin{array}{c}\text { Górna granica } \\
\text { powtarzalności }\end{array}$ & $\begin{array}{c}\text { Dolna granica } \\
\text { powtarzalności }\end{array}$ & $\begin{array}{c}\text { Liczba powtórzeń } \\
\text { badań LO }\end{array}$ \\
\cline { 1 - 3 } $\mathrm{LOB}=97,00$ & 0,3 & $\mathrm{LOB}_{\mathrm{G}}=97,30$ & $\mathrm{LOB}_{\mathrm{D}}=96,70$ & \multirow{2}{*}{10} \\
\cline { 1 - 4 } & 0,4 & $\mathrm{LOM}_{\mathrm{G}}=87,90$ & $\mathrm{LOM}_{\mathrm{D}}=87,10$ & \\
\hline
\end{tabular}

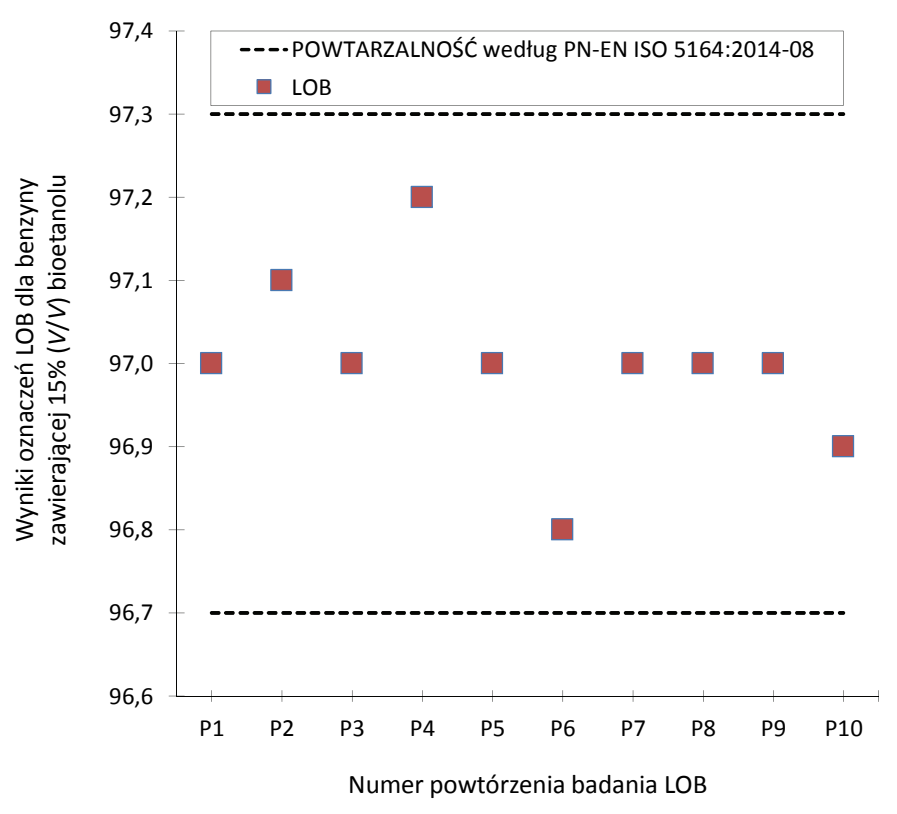

Rys. 2a. Wyniki oznaczeń liczby oktanowej badawczej (LOB) dla paliwa E15

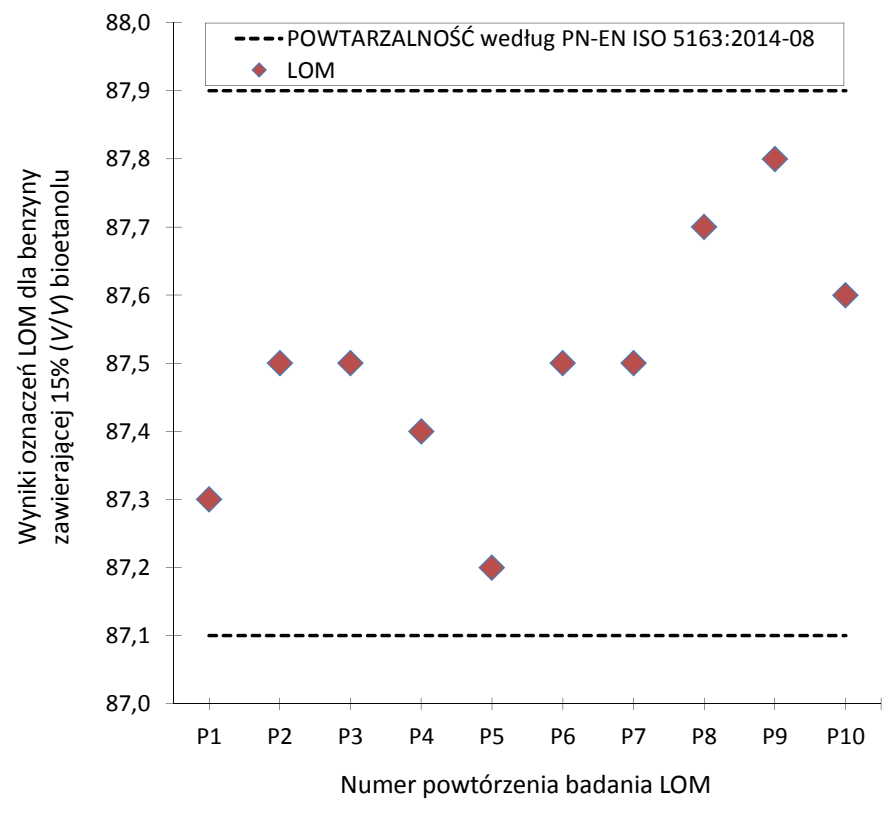

Rys. 2b. Wyniki oznaczeń liczby oktanowej motorowej (LOM) dla paliwa E15 
Tablica 7. Wyniki oznaczeń LOB według PN-EN ISO 5164:2014-08 i LOM według PN-EN ISO 5163:2014-08 paliwa E20

\begin{tabular}{|c|c|c|c|c|}
\hline $\begin{array}{c}\text { Średnia wartość LO } \\
\text { paliwa E20 }\end{array}$ & Powtarzalność & $\begin{array}{c}\text { Górna granica } \\
\text { powtarzalności }\end{array}$ & $\begin{array}{c}\text { Dolna granica } \\
\text { powtarzalności }\end{array}$ & $\begin{array}{c}\text { Liczba powtórzeń } \\
\text { badań LO }\end{array}$ \\
\cline { 1 - 3 } $\mathrm{LOB}=98,60$ & 0,3 & $\mathrm{LOB}_{\mathrm{G}}=98,90$ & $\mathrm{LOB}_{\mathrm{D}}=98,30$ & \multirow{2}{*}{10} \\
\cline { 1 - 4 } & 0,4 & $\mathrm{LOM}_{\mathrm{G}}=88,90$ & $\mathrm{LOM}_{\mathrm{D}}=88,10$ & \\
\hline
\end{tabular}

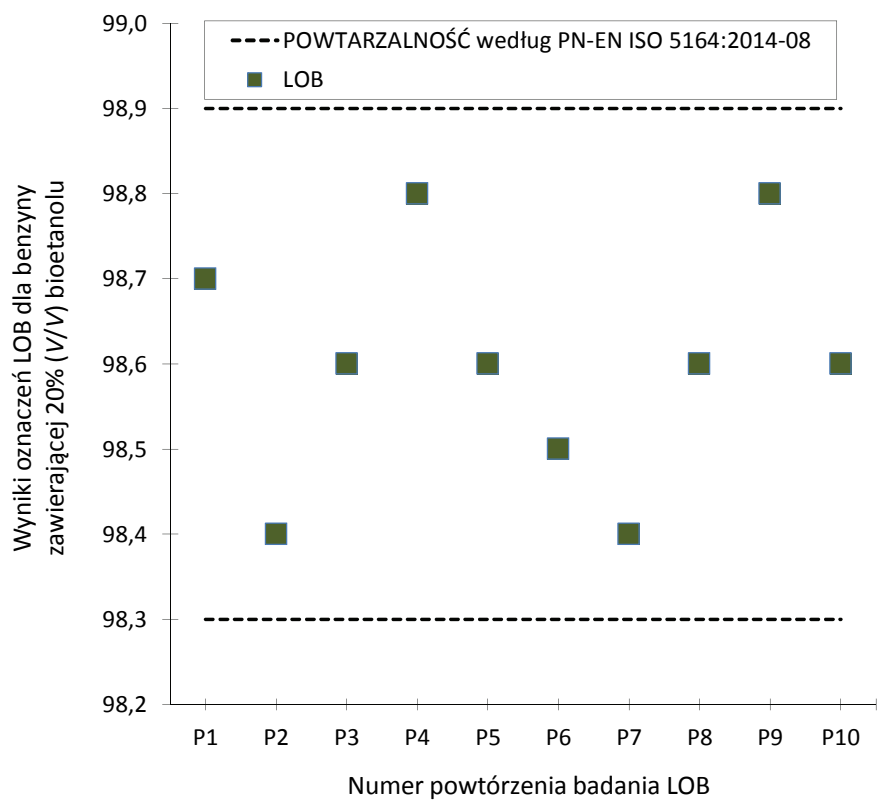

Rys. 3a. Wyniki oznaczeń liczby oktanowej badawczej (LOB) dla paliwa E20

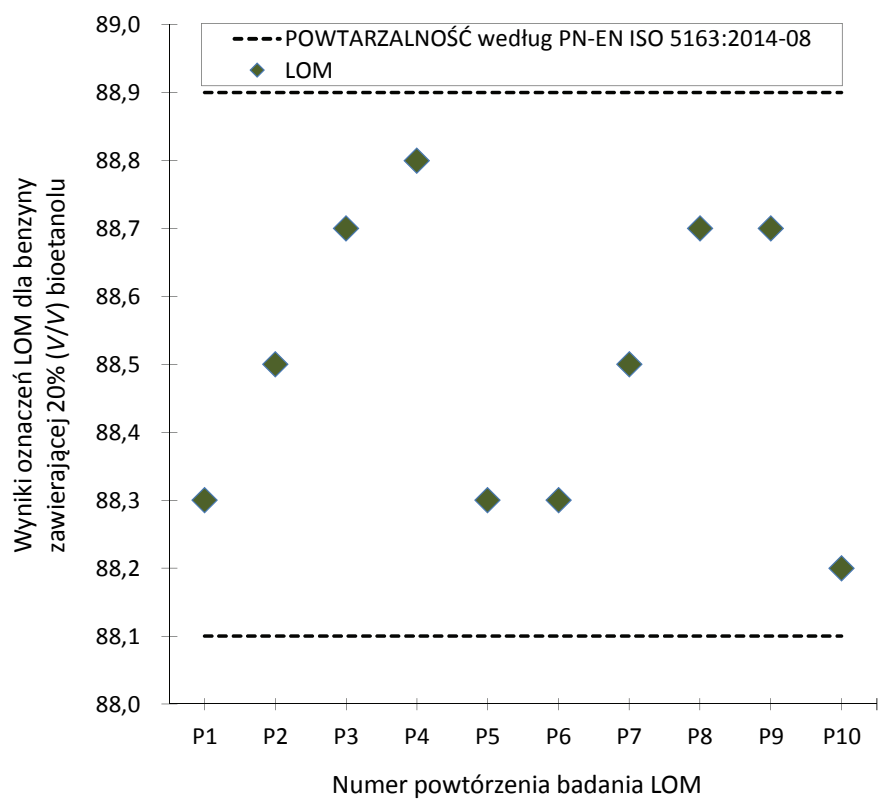

Rys. 3b. Wyniki oznaczeń liczby oktanowej motorowej (LOM) dla paliwa E20

Tabela 8. Wyniki oznaczeń LOB według PN-EN ISO 5164:2014-08 i LOM według PN-EN ISO 5163:2014-08 paliwa E25

\begin{tabular}{|c|c|c|c|c|}
\hline $\begin{array}{c}\text { Średnia wartość LO } \\
\text { paliwa E25 }\end{array}$ & Powtarzalność & $\begin{array}{c}\text { Górna granica } \\
\text { powtarzalności }\end{array}$ & $\begin{array}{c}\text { Dolna granica } \\
\text { powtarzalności }\end{array}$ & $\begin{array}{c}\text { Liczba powtórzeń } \\
\text { badań LO }\end{array}$ \\
\cline { 1 - 3 } $\mathrm{LOB}=99,10$ & 0,3 & $\mathrm{LOB}_{\mathrm{G}}=99,40$ & $\mathrm{LOB}_{\mathrm{D}}=98,80$ & \multirow{2}{*}{10} \\
\cline { 1 - 4 } & 0,4 & $\mathrm{LOM}_{\mathrm{G}}=90,40$ & $\mathrm{LOM}_{\mathrm{D}}=89,60$ & \\
\hline
\end{tabular}

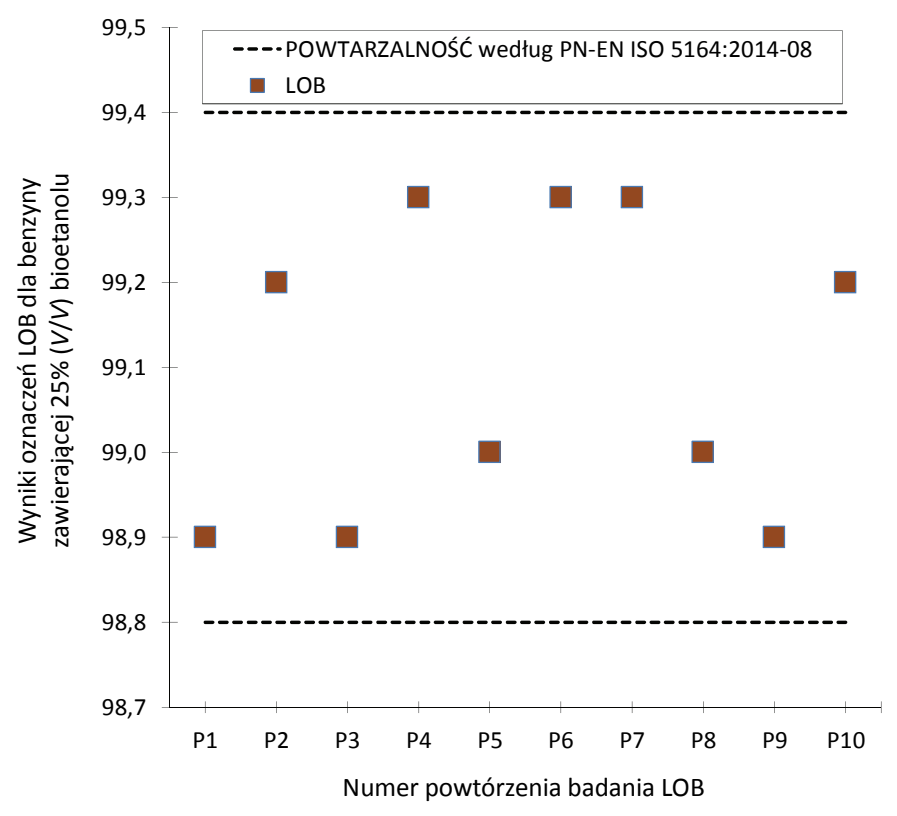

Rys. 4a. Wyniki oznaczeń liczby oktanowej badawczej (LOB) dla paliwa E25

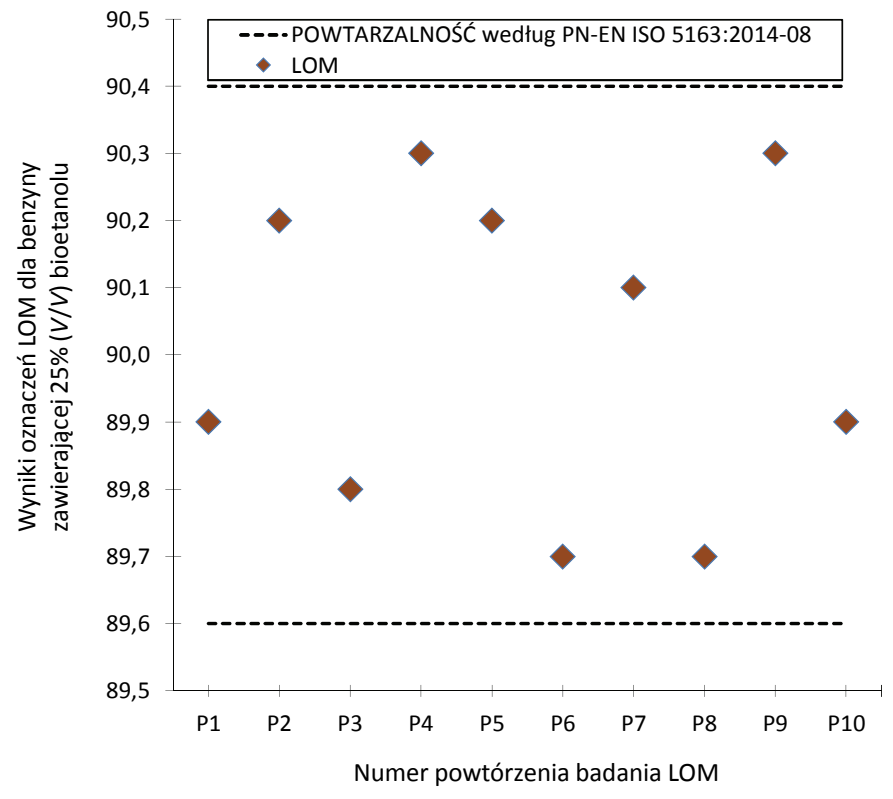

Rys. 4b. Wyniki oznaczeń liczby oktanowej motorowej (LOM) dla paliwa E25 


\section{Podsumowanie}

Na podstawie wyników badań przeprowadzonych w INiG - PIB i zamieszczonych w tablicach 3 i 5-8 oraz przedstawionych na rysunkach 1-4 można wytypować procentowy skład mieszaniny bazowej benzyny i bioetanolu do uzyskania paliwa przeznaczonego do zasilania silników o zapłonie iskrowym, spełniającego według normy PN-EN 228:2013-04 minimalne wymagania jakościowe dotyczące liczb oktanowych benzyn silnikowych 95 i 98. Ponadto zgodnie z programem Horyzont 2020 i wytypowanym na podstawie warsztatów „Business Plan for the CEN Workshop" zakresem badań parametrów fizykochemicznych według EN 228 dla potencjalnej specyfikacji benzyny silnikowej zawierającej od $20 \%$ do $25 \%$ ( $V / V)$ bioetanolu - paliwem spełniającym wszystkie podane kryteria oceny jest bazowa benzyna silnikowa zawierająca 20\% ( $V / V)$ bioetanolu (paliwo E20) - tablica 3.

Natomiast $\mathrm{z}$ porównania parametrów fizykochemicznych paliw E15-E25 z wymaganiami normy PN-EN 228:2013-04, stosowanej do oceny jakości paliwa E10, wynika, że parametry tych paliw w większości spełniają wymagania jakościowe paliwa E10, a przekroczenia dopuszczalnych normowanych granic ściśle zależą od zwiększonej procentowej zawartości bioetanolu w benzynie silnikowej (tablica 3, punkty 6 i 7b).

W przypadku paliwa E15 przekroczenie wartości parametru destylacji normowanej według PN-EN 228:2013-04 (tablica 3, punkt 3a) może prowadzić do wytwarzania niepożądanych korków paliwowych w układzie zasilania paliwem, natomiast przekroczenie wartości parametru destylacji dla paliw E20-E25 (tablica 3, punkt 3b) może skutkować brakiem płynności pracy silnika w warunkach nieustalonych, na przykład podczas gwałtownego zwiększania prędkości obrotowej, i powodować ograniczenia w możliwości osiągnięcia maksymalnej mocy silnika [5]. Porównując wpływ procentowego udziału bioetanolu w bazowej benzynie silnikowej na wartości otrzymywanych parametrów jakościowych, zaobserwowano nieliniowy przyrost liczby oktano- wej badawczej (tablice 5-8), oraz występowanie w przypadku prężności par zarówno dodatnich, jak i ujemnych efektów mieszania paliw (tablica 3, punkt 2). Z badań prowadzonych w Instytucie nad jakością benzyn silnikowych wiadomo, że bioetanol powoduje nieaddytywne zmiany właściwości takich parametrów jak, między innymi, liczby oktanowe, prężność par czy skład frakcyjny, co finalnie może prowadzić do niespełnienia wymagań jakościowych zmieszanego paliwa [7]. Dlatego bardzo ważne jest monitorowanie tych parametrów podczas komponowania różnych mieszanin paliw etanolowych.

Badania liczb oktanowych zestawionych w INiG - PIB paliw silnikowych E10-E25, wykonywane zgodnie z normami PN-EN ISO 5164:2014-08 (LOB), PN-EN ISO 5163:2014-08 (LOM) i podaną w nich precyzją oznaczeń LO benzyn silnikowych zawierających do $25 \%(V / V)$ bioetanolu, pozwoliły wykazać, że wszystkie otrzymane wyniki liczb oktanowych mieszczą się w normowanych granicach powtarzalności, a uzyskane rezultaty mogą posłużyć do przeprowadzenia walidacji wyżej wymienionych metod dla benzyn silnikowych o podwyższonej, w granicach od $15 \%$ do $25 \%(V / V)$, zawartości bioetanolu.

Dobranie odpowiedniej bazy paliwowej o stosunkowo małych wartościach liczb oktanowych umożliwia prowadzenie badań LOB i LOM benzyn silnikowych zawierających do $25 \%(V / V)$ bioetanolu bez konieczności stosowania mieszanin wzorcowych PRF/TEL (tablica 4), co wiąże się z dodatkowymi wymaganiami norm PN-EN ISO 5164:2014-08 (LOB) i PN-EN ISO 5163:2014-08 (LOM).

Badania wpływu procentowej zawartości bioetanolu w benzynie silnikowej na poziom otrzymywanych wartości liczb oktanowych (badawczej, motorowej) umożliwiają gruntowne i kompleksowe rozeznanie tej zależności, a otrzymane wyniki mogą posłużyć do efektywniejszego zarządzania strumieniami komponentów kierowanych do produkcji benzyny silnikowej.

Prosimy cytować jako: Nafta-Gaz 2016, nr 11, s. 975-983, DOI: 10.18668/NG.2016.11.12

Artykuł nadesłano do Redakcji 7.10.2016 r. Zatwierdzono do druku 11.10.2016 r.

Artykuł powstał na podstawie pracy statutowej pt. Badania wptywu zwiększonego udziału bioetanolu w benzynie silnikowej na wielkość liczby oktanowej - praca INiG - PIB na zlecenie MNiSW; nr zlecenia: 0008/TE/15/01, nr archiwalny: DK-4100-8/15.

\section{Literatura}

[1] Bioetanol. Strona internetowa Stowarzyszenia Krajowa Izba Biopaliw, 27.03.2011; http://kib.pl/index.php/component/ content/article/29-kib/wiedza/147-bioetanol (dostęp: sierpień 2015).

[2] CE2 Centrum Edukacji: Walidacja i potwierdzenie metod badań chemicznych i mechanicznych oraz szacowanie niepew- ności. Materiały szkoleniowe CE2 dla INiG - PIB, Kraków 2013.

[3] Dybich K.: Wpływ zawartości i jakości bioetanolu w paliwach do silników ZI na oznaczenie liczby oktanowej. Nafta-Gaz 2015, nr 7, s. 520-528.

[4] Europejski Komitet Normalizacyjny. Wikipedia; https:// 
pl.wikipedia.org/wiki/Europejski_Komitet_Normalizacyjny (dostęp: sierpień 2015).

[5] Janków A., Garstecki Ł.: Jakość paliw - analiza porównawcza jakości paliw dostępnych $w$ Polsce $i$ wybranych krajach Unii Europejskiej (Niemcy, Austria, Łotwa, Irlandia, Czechy). Urząd Ochrony Konkurencji i Konsumentów, Warszawa 2007.

[6] Pałuchowska M., Jakóbiec J.: Specyfikacje jakościowe benzyny silnikowej E10. Nafta-Gaz 2011, nr 11, s. 825-830.

[7] Rogowska D.: Problem nieaddytywnych efektów mieszania dla parametru ,prężność par” $w$ trakcie blendingu biopaliwa E85. Nafta-Gaz 2010, nr 3, s. 211-215.

[8] Stacje benzynowe.pl; http://www.stacjebenzynowe.pl (dostęp: sierpień 2015).

[9] WNP.PL (MS): Producenci bioetanolu zapewniaja o bezpieczeństwie paliwa E10. Portal gospodarczy WNP.pl, 14.03.2011; http://nafta.wnp.pl/producenci-bioetanoluzapewniaja-o-bezpieczenstwie-paliwa-e10,134792_1_0_0. html (dostęp: sierpień 2015).

\section{Akty prawne i normatywne}

[10] Dokument CEN nr N 1690 z dnia 2014-06-04 Proposed Project Horizon 2020 programme.
[11] Norma PN-EN ISO 5163:2014-08 Przetwory naftowe - Oznaczanie odporności benzyny samochodowej i benzyny lotniczej na spalanie stukowe - Metoda motorowa.

[12] Norma PN-EN ISO 5164:2014-08 Przetwory naftowe - Oznaczanie odporności benzyny samochodowej na spalanie stukowe - Metoda badawcza.

[13] Warsztaty Business Plan for the CEN Workshop z 27 czerwca 2014 r. Mid-blend ethanol petrol (E20-E25) fuel - Requirements and test methods.

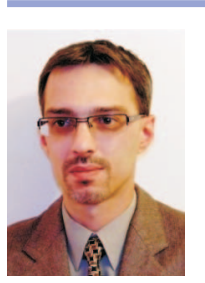

Mgr inż. Kornel DYBICH

Starszy specjalista badawczo-techniczny w Zakładzie Oceny Właściwości Eksploatacyjnych. Instytut Nafty i Gazu - Państwowy Instytut Badawczy ul. Lubicz 25 A

31-503 Kraków

E-mail: kornel.dybich@inig.pl

\section{OFERTA}

\section{ZAKŁAD OCENY WŁAŚCIWOŚCI EKSPLOATACYJNYCH}

Zakres działania:

- $\quad$ ocena w testach laboratoryjnych właściwości fizykochemicznych oraz użytkowo eksploatacyjnych wg najnowszych procedur badawczych, zarówno europejskich, jak i amerykańskich:

" paliw ciekłych, biopaliw i biokomponentów,

" środków smarowych, w tym: olejów silnikowych, przekładniowych i przemysłowych, zarówno świeżych, jak i przepracowanych;

- pełny zakres usług w zakresie nowoczesnego planowania i monitorowania właściwości olejów smarowych w eksploatacji wraz z ocena zachodzacych w nich zmian, doradztwo i ekspertyzy w zakresie użytkowania olejów niewłaściwej jakości lub ich niewłaściwej eksploatacji;

- $\quad$ szeroki zakres ocen stanowiskowych właściwości trybologicznych paliw, środków smarowych oraz cieczy hydraulicznych;

- oceny liczb oktanowych i cetanowych w testach silnikowych wg procedur europejskich i amerykańskich;

- $\quad$ jedyne w kraju oceny właściwości użytkowo-eksploatacyjnych paliw silnikowych wg ogólnoeuropejskich testów silnikowych opracowanych przez CEC i wymaganych między innymi przez Worldwide Fuel Charter;

- oceny kompatybilności dodatków do paliw i olejów smarowych, usługi eksperckie w zakresie problemów związanych z niekompatybilnością wymienionych produktów w eksploatacji;

- oceny właściwości użytkowo-eksploatacyjnych paliw i olejów smarowych w badaniach eksploatacyjnych;

- $\quad$ usługi eksperckie w zakresie wpływu jakości paliw na możliwości powstania dysfunkcji i uszkodzeń silnikowych układów wtrysku paliwa;

- badania procesów regeneracji filtrów cząstek stałych na stanowisku silnikowym, doradztwo w zakresie eksploatacji układów filtracji spalin wyposażonych w filtry cząstek stałych.

Kierownik: dr inż. Stanisław Oleksiak

Adres: ul. Łukasiewicza 1, 31-429 Kraków

Telefon: 126177574

Faks: 126177577,126177522

E-mail: stanislaw.oleksiak@inig.pl 